DOI: $10.12775 /$ szhf.2013.010

\title{
Hermanna Lotze teleologiczna koncepcja piękna
}

W połowie XIX stulecia w życiu duchowym obszaru kultury niemieckiej obserwujemy specyficzny zwrot. Filozoficzne systemy spekulatywne, szczególnie dominujący wcześniej w kluczowych dziedzinach humanistyki Heglowski idealizm, ustępują pola naukom „ścisłym”. Poznanie wyrosłe z poszczególnych gałęzi przyrodoznawstwa, dla Hegla mające stosunkowo małe znaczenie, gdyż $\mathrm{w}$ jego systemie stanowiło ono najniższy stopnień obiektywizacji ducha, staje się jednym z głównych motorów refleksji filozoficznej, spychając filozofowanie w duchu heglowskim na drugi plan. Gdyby autor Fenomenologii ducha dożył wieku Kanta, mógłby tego procesu doświadczyć zapewne jeszcze osobiście.

Zwrot następujący w nauce stanowił oczywiście dla filozofii szczególne wyzwanie, ale nie oznaczał zniszczenia jej podstawowego pnia, czyli metafizyki. W odróżnieniu od stanowiska Hegla wyrażającego, jak się powszechnie sądzi, lekceważenie dla faktów z zakresu wiedzy przyrodniczej, podjęta przez filozofię poheglowską próba obrony metafizyki przed inwazją nauk pozytywistycznych (którym towarzyszą pierwsze znaczne osiągnięcia techniki), staje się próbą „przewartościowania wartości”. W przeciwieństwie do angielsko-francuskiego pozytywizmu, mocno przywiązanego do faktów empirycznych i unikającego metafizyki, w kulturze niemieckiej, jak zwraca uwagę choćby Ernst von Aster, „utrzymuje się nadal tendencja filozoficzno-spekulatywna, dążność do wypracowania całościowego obrazu świata, integrującego 
przyrodę i życie duchowe"1. Zaowocowało to próbą zbudowania metafizyki w sposób indukcyjny, czyli oparcia jej na podstawie empirycznej.

Prekursorami takiej tendencji byli przede wszystkim Gustav Theodor Fechner (1801-1887) i Hermann Lotze (1817-1881), obaj znani jako przedstawiciele nauk szczegółowych, Fechner był z wykształcenia fizykiem, a Lotze lekarzem i fizjologiem. Jeden i drugi uznawali doświadczenie za fundament poznania. Dla Fechnera empiryczną podstawę metafizyki stanowiło doświadczenie życia psychicznego. Jego filozofia przybiera postać panpsychizmu i paralelizmu psychofizycznego, w ramach których zakłada się, że własności psychiczne obecne są $\mathrm{w}$ całej przyrodzie (to znaczy również u roślin i prymitywnych zwierząt, nie wykluczając nawet ciał niebieskich). Za podstawę życia i biegu świata, przyjmuje się tu pewną niezniszczalną zasadę duchową. W ten sposób, jak twierdzi Fechner, metafizyka przywraca zjawiskom życie, odebrane im w dostosowującym je do swych potrzeb i użytkowych celów suchym procesie naukowego poznania.

Dla Lotzego punktem wyjścia wiedzy staje się obserwacja tego, co obiektywnie jest i co może być przedmiotem badania nauk pozytywnych, czyli mechanicznych prawidłowości rządzących światem przyrody. Jest on twórcą koncepcji, której credo sprowadza się do tego, by to co ",jest", byt badany przez nauki, przeciwstawić wartościom, które nie tyle „są”, co obowiązują. Próba uratowania filozofii ma więc, zdaniem Lotzego polegać na uczynieniu z niej nauki o wartościach. Jak stwierdza Lotze, prawidłowości będące przedmiotem nauk pozytywnych nie mogą być prawidłowościami bez celu, odwrotnie, muszą być podporządkowane określonemu celowi, czyli posiadać charakter teleologiczny. W przyrodzie wszelkie fakty zachodzą wprawdzie według determinujących je praw, prawa te jednak objęte są wspólną metafizyczną zasadą, której źródło stanowi czynnik duchowy. To zasadę duchową należy rozpatrywać w perspektywie celu. Rządzi ona mechanizmem materialnego świata posługując się nim dla urzeczywistnienia celu nadrzędnego, który stanowi dobro. W konsekwencji, zdaniem Lotzego, oparcie dla metafizyki tworzy etyka. W przeciwieństwie do Fechnera, w przypadku poglądów którego mówić można o pewnym modelu panteizmu, stanowisko Lotzego skłania się bardziej w stronę filozoficznego teizmu.

W niniejszym krótkim artykule nie chciałbym koncentrować się na ostatecznych wnioskach wynikających z nauki Lotzego, które były z takich czy innych pozycji krytykowane i którym, jak można sądzić, filozof ten „zawdzię-

\footnotetext{
${ }^{1}$ Ernst von Aster, Historia filozofii, tłum. J. Szewczyk, Warszawa 1969, s. 433.
} 
cza” stosunkowo nikłą popularność swej koncepcji „przegrywającej” pod względem atrakcyjności chociażby z opanowującą w jego czasach niemieckie „salony” metafizyką woli Schopenhauera. Natomiast bliżej zamierzam omówić stanowiącą fundamentalne ogniwo systemu Lotzego koncepcję piękna, przedstawioną w niewielkiej objętościowo rozprawie Über den Begriff der Schönheit (O pojęciu piękna, 1845).

Jednym z podstawowych twierdzeń estetyki Lotzego jest następująca teza dotycząca wartości: „Zdajemy sobie sprawę, że wszystko, co ma w świadomości uzyskać wartość, musi zastać duszę nie w bezruchu (nicht in Ruhe), lecz w żywym lub powstrzymywanym dążeniu"2.

Wartość, tu można wskazać na analogię do koncepcji Fechnera, stanowi dla Lotzego czynnik ożywiający, po który sięga filozofia postawiona w obliczu faktu, że jej dotychczasowy punkt odniesienia, byt jako coś, co obiektywnie „jest”, na skutek penetrującej działalności nauk szczegółowych został pozbawiony tożsamości, rozczłonkowany i okaleczony. W jaki sposób piękno staje się wartością?

Tu Lotze odwołuje się do Kanta, dla którego piękno sprowadzało się do zgodności stosunków, w jakich przynależący do przyrody przedmiot pozostaje z wolną grą naszych władz poznawczych. W nauce Kanta oprócz faktu, że przedmiot $\mathrm{w}$ procesie poznania podporządkowuje się koniecznym prawom intelektu, istotne znaczenie ma cecha, że poza tym procesem wyodrębnia on jeszcze związki i zależności odpowiadające dążeniu do podporządkowania różnorodności poznania jednej wspólnej zasadzie. Zjawisko to królewiecki filozof nazwał przejawem przychylności (Gunst) ze strony przyrody ${ }^{3}$, świadczącym o jej celowości dla naszych władz poznawczych i będącym zarazem dla podmiotu źródłem uczucia rozkoszy $(\text { Lust })^{4}$, określonym w Krytyce władzy sądzenia jako uczucie witalne (Lebensgefühl) $)^{5}$.

\footnotetext{
${ }^{2}$ H. Lotze, Über den Begriff der Schönheit, Göttingen 1845, s. 7.

${ }^{3}$ Por. I. Kant, Krytyka władzy sądzenia, tłum. J. Gałecki, Warszawa 1964, s. 343 [J. Gałecki termin Gunst oddaje przez „przychylność” i przez „życzliwość”]. W odnośnym fragmencie u Kanta czytamy: „Pomyślana przez nas zgodność przyrody w różnorodności jej praw szczegółowych z naszą potrzebą znalezienia dla nich zasad ogólnych musi być, zgodnie z całym naszym rozumieniem rzeczy, uznana za przypadkową, ale zarazem za niezbędną dla potrzeb naszego intelektu, a więc za celowość, dzięki której przyroda pozostaje w zgodzie z naszym, ale tylko ku poznaniu skierowanym, zamiarem" (tamże, s. 35).

${ }^{4}$ „Osiągnięcie każdego zamierzenia połączone jest z uczuciem rozkoszy...” (tamże, s. 36).

${ }^{5}$ Por. tamże, s. 62 (Immanuel Kant, Akademie-Ausgabe, Bd. 5, s. 204).
} 
Przedmiot rozpatrywany z tego punktu widzenia, stwierdza Lotze, nie jest piękny w tym sensie, że piękno jako wartość miałoby mu przysługiwać obiektywnie. Za cechę przedmiotu można tu tylko przyjąć możliwość, że pozostaje on w przypadkowej zgodności z duchowymi władzami człowieka, wzbudzając określone uczucia. Własności oraz stosunki własności przedmiotu, ale takie, które w niczym nie przyczyniają się do poznania i są dla intelektu obojętne, choć pozostają skierowane na cel, wzmagają żywotność ducha, który w efekcie, jak poetycko wyraża się Lotze, „obejmuje niejako ciepłem własnych uczuć zimne światło pobudzającej go formy (Gestalt)"6.

$\mathrm{W}$ tej perspektywie piękno przedmiotu nie posiada wartości, która występowałaby w świecie zewnętrznym jako własność rzeczywista. Owa wartość polega na wewnętrznym odczuciu przedmiotu. Własności piękna nie należy mieszać z obiektywną prawdą na temat zewnętrzności, ale nie oznacza to bynajmniej, że obowiązuje ona w mniejszym stopniu aniżeli w sytuacji, gdyby rzeczywiście było ono własnością świata zewnętrznego. W tym kontekście Lotze akcentuje różnicę pomiędzy „bezwartościowym” pojęciem prawdy a jej treścią. Stwierdzenie, że cel poznania oznacza pozyskanie prawdy o istotnych własnościach rzeczy, która to prawda stale się pomnaża i ewoluuje, pozwalając nam zrozumieć i pojąć świat - twierdzi filozof - jest z całą pewnością słuszne. Lecz gdyby miało ono oznaczać postulat, by podmiot, określał swój cel jako „lustro dla tego, co nie myśli”" , prowadziłoby to do niedorzeczności. Niedorzeczność taka miałaby zaś miejsce, gdybyśmy piękno uznali za obiektywną cechę rzeczy zewnętrznej, a nie za sposób pobudzenia naszego umysłu.

$\mathrm{Z}$ drugiej strony, wnioskuje Lotze, przyjmując, że piękno posiada ważność $\mathrm{i}$ istnieje tylko „w nas”, akceptujemy stan, w którym zarówno pojęcie wartości, jak i nasz obraz świata jako całości pozostają niepełne. Jeśli więc piękno jest już obowiązującą własnością, to staje się własnością domyślną, na podstawie której można wnosić, że jako zasada ożywiająca przenika ono cały istniejący byt (das Seiende). Prawdziwą i trwałą wartość może bowiem uzyskać dla nas tylko to, w czego położenie potrafimy się „wczuć” i czego istnieniem

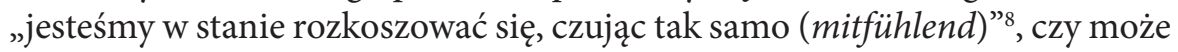
raczej, jak powiedziałby Kant, czując w sposób powszechnie ważny. W przeciwnym wypadku nadal pozostawalibyśmy w obliczu świata „bez wartości”, przedstawiającego jedynie obraz chaosu, tworzonego przez zbiór nie powią-

\footnotetext{
${ }^{6}$ H. Lotze, dz. cyt., s. 19.

7 Tamże, s. 20.

8 Tamże, s. 22.
} 
zanych ze sobą, suchych, często sprzecznych i przypadkowych faktów. W takiej sytuacji groziłoby nam niebezpieczeństwo, że piękno łatwo dałoby się sprowadzić do poziomu właśnie przypadkowych faktów, co znaczy, że uleglibyśmy pozorowi zaistnienia tylko przypadkowej zgodności cech przedmiotu ze strukturą władz intelektualno-duchowych. Lotze stara się uniknąć takiej relacji, dla której charakterystyczne jest, że jak to ocenia, myśli i uczucia podmiotu „unoszą się" nad pozbawionymi życia własnościami zewnętrznymi.

W konsekwencji zasadniczy dla estetyki Lotzego postulat jedności w stosunku do fenomenu piękna wysunięty zostaje na innej podstawie. Zacytujmy w całości fragment, w którym postulat ten jest explicite sformułowany:

Wymagamy zatem rzeczy dwojakiej. Nie tylko, aby siły nadające przedmiotowi piękne stosunki uznać za jego własne działanie określające jego istnienie, istotę i rozwój, lecz także, aby piękno, które pojawia się w nieskończonej różnorodności rzeczy w sposób równie różnorodny, traktować jako je wszystkie ożywiającą jedność; tak aby uniknąć [tego], że różne przypadki zgodności pomiędzy rzeczami a nami dają tak samo różne piękna, jak to ma miejsce gdy pożytku dawanego przez przedmioty nie można zjednoczyć pod wspólnym pojęciem, ponieważ opiera się on właśnie na przypadkowych, występujących jednostkowo stosunkach?.

W powyższym fragmencie Lotze stara się zaprezentować analogię pomiędzy poznaniem a odczuciem piękna. W pierwszym przypadku mamy do czynienia ze zgodnością przedmiotu poznania, z jego pojęciem, czyli używając języka Lotzego, zgodnością materii i myśli. Podobnie jest i w przypadku drugim: piękno jest tu stosunkiem zgodności pomiędzy materią i myślą, tyle że zgodność ta posiada ponadto charakter relacji celowej, wybiegającej poza poznanie czysto intelektualne.

Odtworzenie idei relacji celowości w interpretacji Lotzego jest zadaniem dość skomplikowanym. W skrócie można byłoby powiedzieć, że jej zaistnienie wymaga spełnienia trzech warunków. Warunkiem pierwszym jest myśl zawierająca sens wartości i dążąca do jej urzeczywistnienia (zmaterializowania), drugim szereg konkretnych działających przyczyn, które to urzeczywistnienie czynią możliwym, trzecim ogólne prawa regulujące, niezależnie od konkretnych przyczyn działanie wszelkich sił tak, że owo działanie pozostaje nakierowane na cel. W dziedzinie poznania, gdzie myślenie, budując obiektywne pojęcie przedmiotu nie może uwzględnić jego wszystkich, czę-

9 Tamże, s. 22-23. 
sto przecież sprzecznych ze sobą cech i w efekcie wybiera przy tej budowie niektóre jego właściwości, inne zaś musi pominąć, zgodność materii i myśli uzyskiwana jest w sposób szczegółowy. Pojawia się ona mocą intelektu, jako warunek bez spełnienia którego świat pozostawałby zawsze czymś bezsensownym. Gdy jednak relacji celowości podporządkowane zostaną także te cechy i własności przedmiotu, które dla poznania okazywały się przypadkowe, wówczas objawia się zjawisko piękna, które przezwycięża ową przymuszającą rzeczy konieczność procesu charakterystyczną dla poznania poszukującego wyłącznie prawdy. Piękno jest świadectwem na to, że wewnętrzna, obecna w poznaniu sprzeczność pomiędzy materią i myślą może jednak zostać usunięta i wówczas świat okazuje się tworem jednorodnym, nie zaś efektem połączenia obu tych czynników. W koncepcji Lotzego piękno nie jest więc zjawiskiem, lecz sensem zjawisk, stanowiąc objawienie leżącej u podstawy świata myślącej duchowości (Ausstrahlung des denkenden Geistes) ${ }^{10}$.

Odczuciu piękna, jako zgodności wszystkich stosunków materii i myśli, towarzyszy wspomnienie rozbicia świata na materię (byt) i myśl. Jednakże, postuluje Lotze, zgodność ta nigdy nie może ostatecznie zostać potwierdzona w formie reguły, lecz zachowuje charakter przypadku jako swego rodzaju szczęśliwe wydarzenie, wywołujące uczucie rozkoszy. Zawsze bowiem istnieje możliwość, a właściwie pewność, że siły i stosunki, którym podlega przedmiot i które w danym momencie podporządkowują się jednoczącej myśli, w bliższej lub dalszej przyszłości ponownie zaczną przejawiać opór, wykazując dążenie do autonomicznego rozrostu. Zdaniem Lotzego to właśnie tego rodzaju opór staje się źródłem zjawiska brzydoty.

Brzydota sprzeciwiająca się dążeniu jakiejś struktury do przypisanego jej celu nie jest oczywiście wartością samoistną, gdyż jej genezę ustanawia negacja. Ale nie jest też ona ot tak po prostu zaprzeczeniem piękna. Raczej stanowi jego swoisty warunek wstępny, który należy zmienić. Bez owego warunku oraz jego przemiany piękno właściwie nie mogłoby zaistnieć.

W tym kontekście w rozprawie Lotzego pojawia się wprowadzone do estetyki przez Schillera przeciwstawienie pojęć wdzięku i godności. Pojęcia te interpretowane są tu jednak inaczej, aniżeli w koncepcji autora Wallensteina. Zdaniem Lotzego o wdzięku można byłoby mówić dopiero wówczas, gdyby piękno potrafiło zakryć źródłowe przeciwieństwo (brzydotę) tak szczelnie, że refleksja duchowa zdolna byłaby o owym przeciwieństwie całkowicie

\footnotetext{
${ }^{10}$ Por. tamże, s. 29.
} 
zapomnieć. Wdzięk jest zjawiskiem naturalnym, beztroskim i niewinnym, w obliczu którego nie pamięta się o sprzecznościach. Wzbudza on zachwyt, ale tylko w sytuacji gdy nasza świadomość ulega mu i przezwycięża, jak pisze Lotze „wspomnienie o przezwyciężonych niebezpieczeństwach i goryczy walki"11.

Istotną cechą życia jest jednak żywa i aktywna świadomość, która ani nie odsuwa od siebie wiedzy o materii, ani nie popada w obliczu rzeczywistości empirycznej w bezmyślne otępienie. Zawsze wypatruje niebezpieczeństwa przeciwieństw, naruszających postulowaną harmonię teleologiczną i z góry stara się poszukiwać środków do ich pokonania. Dlatego właściwe piękno zawsze powinno „ukazywać ranę, którą leczy”12 i wykazując swą przewagę nad poprzedzającym je stanem brzydoty cieszyć nas blaskiem wzniosłości, który nie przysługuje bynajmniej pięknu pozostającemu w stanie beztroski i nie znającemu trudu walki. Przyjmując wzniosłość za jedną z podstawowych cech konstytuujących pojęcie piękna, Lotze przekracza więc tradycyjne, ciągnące się od Burke'a przeciwstawienie obu tych pojęć, nadając tym samym estetyce rangę bardzo ważnego członu w systemie stworzonej przez siebie metafizyki. W koncepcji tej przedmiot sam w sobie nie jest piękny, ale nie jest też wzniosły. Zdolność do wzbudzania wzniosłości nadaje mu dopiero granicząca z nim zasada duchowa, która w dalszej kolejności przyczynia się do lepszej realizacji zadań charakterystycznych dla etyki ${ }^{13}$.

Podobne rozwiązania odnajdziemy w nieco późniejszej od koncepcji Lotzego estetyce Eduarda von Hartmanna. Również i tu kluczowe przy pojmowaniu pojęcia piękna jest pojęcie celowości. Hartmann nie cenił co prawda dokonań Lotzego z tej dziedziny zbyt wysoko, trafnie jednak ujął podstawową myśl jego koncepcji mówiąc, że: „idea piękna jest formą rozwoju twórczej zasady duchowej świata (Weltseele) i tylko tej ostatniej przypisać można piękno w najpełniejszym sensie"14, ponieważ tylko ona jest w stanie znieść i przezwyciężyć dysonanse zawarte w istnieniu pojedynczym. Podobnie sformułowaną tezę autor Filozofii nieświadomego przedstawia także we własnej koncepcji estetycznej. Piękno, zarówno przyrody, jak i sztuki wy-

\footnotetext{
${ }^{11}$ Tamże, s. 34.

12 Tamże.

${ }^{13}$ Chodzi tu niewątpliwie o nawiązanie do Kantowskiej koncepcji, że wartości estetyczne mogą stać się zastępczymi przedmiotami idei dobra.

${ }^{14}$ E. von Hartmann, Ausgewählte Werke, Bd. 3, Ästhetik. Erster historisch-kritischer Teil: Die deutsche Ästhetik seit Kant, Leipzig, b.r.w., s. 105.
} 
pływa tu z twórczej zasady duchowej świata (Weltgeist), której twory, jako obiektywno-realne zjawiska, działają według logicznych praw. Ale w odróżnieniu od koncepcji Lotzego, obowiązując w świecie, zasada duchowa jest dla Hartmanna pierwotnie zasadą nieświadomą i ta oczywista dla niego prawda zaciemniona została $\mathrm{w}$ jego mniemaniu przez teizm ${ }^{15}$ (między innymi ten reprezentowany przez Lotzego).

W króciutkim fragmencie swej Filozofii piękna zatytułowanym Teleologiczne znaczenie piękna w procesie świata Hartmann rekapituluje najważniejsze założenia własnego systemu, który w porównaniu do propozycji Lotzego przedstawia całość nieporównanie bardziej rozbudowaną, zawierającą wiele szczegółowych analiz, a przede wszystkim bardzo wyczerpujące omówienie istoty piękna w poszczególnych grupach zjawisk (od prostych form matematycznych do piękna człowieka). Zasadnicza myśl obu koncepcji jest jednak podobna. W obu przypadkach piękno ukazuje się jako narzędzie służące do "objawienia ducha absolutnego" (Offenbarung des absoluten Geistes) ${ }^{16}$. Duch ten (uświadomiony) jawi się tu jako cel ostateczny. W tej perspektywie idea piękna ujmowana jest jako cel pośredni ${ }^{17}$. Teleologiczna wartość idei piękna jest więc w systemie Hartmanna równie ważna jak w systemie Lotzego. Piękno, zarówno rozpatrywane w sensie makrokosmicznym, jak i z perspektywy mikrokosmosu ludzkiej rzeczywistości, nadaje światu sens, odbierając mu status bezcelowego i bezwartościowego produktu podległego działaniu sił mechanicznej przyczynowości.

\section{Abstract \\ Hermann Lotze's Teleological Conception of Beauty}

Keywords: teleology, beauty, metaphysics, value, spiritual principle

In Germany the positivistic tendencies in sciences in the second half of the $19^{\text {th }}$ century gave rise to attempts of establishing metaphysics on the empirical ground. In his philosophy Hermann Lotze takes the laws of nature as a starting point and considers them from the point of the fundamental teleological principle. The sense

\footnotetext{
15 Tenże, Philosophie des Schönen, Berlin 1924², s. 455.

16 Tamże.

${ }^{17}$ Por. tamże, s. 470.
} 
of beauty, being an important element of this teleology, consists in the feeling of compatibility of the cognitive faculties and the material of cognition, the latter reaching beyond the content of purely intellectual cognition. Following Kant Lotze describes it as a vital feeling which enables him to postulate the existence of spiritual principle governing the mechanism of the material world. 